\title{
Genetic analysis of novel avian A(H7N9) influenza viruses isolated from patients in China, February to April 2013
}

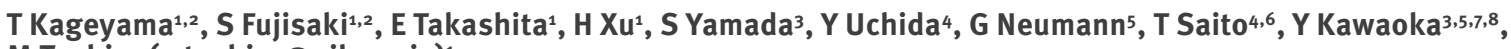

M Tashiro (mtashiro@nih.go.jp)

1. Influenza Virus Research Center, National Institute of Infectious Diseases, Tokyo, Japan

2. These authors contributed equally to this work

3. Division of Virology, Department of Microbiology and Immunology, Institute of Medical Science, University of Tokyo, Tokyo, Japan

4. Influenza and Prion Disease Research Center, National Institute of Animal Health, National Agriculture and Food Research Organization, Ibaraki, Japan

5. Department of Pathobiological Sciences, School of Veterinary Medicine, University of Wisconsin-Madison, Madison, United States

6. The United Graduate School of Veterinary Sciences, Gifu University, Gifu, Japan

7. ERATO Infection-Induced Host Responses Project, Japan Science and Technology Agency, Saitama, Japan

8. Department of Special Pathogens, International Research Center for Infectious Diseases, Institute of Medical Science, University of Tokyo, Tokyo, Japan

Novel influenza viruses of the $\mathrm{H}_{7} \mathrm{~N} 9$ subtype have infected 33 and killed nine people in China as of 10 April 2013. Their haemagglutinin (HA) and neuraminidase genes probably originated from Eurasian avian influenza viruses; the remaining genes are closely related to avian $\mathrm{H}_{9} \mathrm{~N}_{2}$ influenza viruses. Several characteristic amino acid changes in $\mathrm{HA}$ and the $\mathrm{PB}_{2}$ RNA polymerase subunit probably facilitate binding to human-type receptors and efficient replication in mammals, respectively, highlighting the pandemic potential of the novel viruses.

Humans are rarely infected with avian influenza viruses, with the exception of highly pathogenic avian influenza $\mathrm{A}\left(\mathrm{H}_{5} \mathrm{~N}_{1}\right)$ viruses, which have caused 634 infections and 371 deaths as of 12 March 2013 [1]. A few isolated cases of human infection with viruses of the $\mathrm{H}_{7} \mathrm{~N}_{2}, \mathrm{H}_{7} \mathrm{~N}_{3}$, and $\mathrm{H}_{7} \mathrm{~N}_{5}$ subtypes have been reported, but none were fatal [2-11]. In 2003, in the Netherlands, 89 people were infected with an influenza virus of the $\mathrm{H}_{7} \mathrm{~N}_{7}$ subtype that caused conjunctivitis and one fatality $[5,7]$.

On 19 February 2013, an 87 year-old man in Shanghai developed a respiratory infection and died on 4 March, and on 27 February 2013, a 27 year-old pork seller in a Shanghai market became ill and died on 10 March. A 35 year-old woman in Chuzhou City in Anhui province (west of Shanghai), who had contact with poultry, became ill on 15 March 2013, and remains hospitalised in critical condition. There is no known epidemiological relationship among these three cases. A 38 yearold man in Hangzhou (Zhejiang province, south of
Shanghai) became ill on 7 March 2013 and died on 27 March. All four cases presented with respiratory infections that progressed to severe pneumonia and breathing difficulties.

On 31 March 2013, the Chinese Centre for Disease Control and Prevention announced the isolation in embryonated eggs of avian influenza viruses of the $\mathrm{H}_{7} \mathrm{~N}_{9}$ subtype (designated A/Shanghai/1/2013, A/ Shanghai/2/2013, and $A / A n h u i / 1 / 2013$ ) from the first three cases. The sequences of the coding regions of all eight viral genes were deposited in the influenza sequence database of the Global Initiative on Sharing All Influenza Data (GISAID) on 31 March (Table 1). On 5 April 2013, the Hangzhou Center for Disease Control and Prevention deposited the haemagglutinin (HA), neuraminidase (NA), and matrix (M) gene sequences of $A /$ Hongzhou/1/2013 virus (Table 1 ), which was isolated in cell culture from samples obtained from the 38 yearold man.

All four human influenza $\mathrm{A}\left(\mathrm{H}_{7} \mathrm{~N} 9\right)$ viruses are similar at the nucleotide and amino acid levels, suggesting a common ancestor. The HA gene of the novel viruses belongs to the Eurasian lineage of avian influenza viruses and shares ca. 95\% identity with the HA genes of low pathogenic avian influenza $A\left(\mathrm{H}_{7} \mathrm{~N}_{3}\right)$ viruses isolated in 2011 in Zhejiang province (south of Shanghai) (Figure 1, Table 2). The NA gene of the novel viruses is ca. $96 \%$ identical to the low pathogenic avian influenza $A\left(\mathrm{H}_{11} \mathrm{~N} 9\right)$ viruses isolated in 2010 in the Czech Republic (Figure 1, Table 2). 
TABLE 1

Origin of influenza A(H7N9) isolates included in the phylogenetic analysis, China, February-April 2013 (n=7)

\begin{tabular}{|c|c|c|c|c|c|c|}
\hline Segment ID & Segment & Isolate name & $\begin{array}{l}\text { Collection } \\
\text { date }\end{array}$ & Originating Laboratory & $\begin{array}{l}\text { Submitting } \\
\text { Laboratory }\end{array}$ & $\begin{array}{l}\text { Submitter/ } \\
\text { Authors }\end{array}$ \\
\hline EPI439488 & PB2 & \multirow{8}{*}{ A/Shanghai/1/2013 } & \multirow{8}{*}{2013} & \multirow{8}{*}{-} & \multirow{24}{*}{$\begin{array}{c}\text { WHO Chinese } \\
\text { National Influenza } \\
\text { Center }\end{array}$} & \multirow{24}{*}{ Lei Yang } \\
\hline EPI439489 & PB1 & & & & & \\
\hline $\mathrm{EPI} 439490$ & PA & & & & & \\
\hline EPI439486 & $\mathrm{HA}$ & & & & & \\
\hline EPI439491 & NP & & & & & \\
\hline EPI 439487 & NA & & & & & \\
\hline EPI439493 & $M$ & & & & & \\
\hline $\mathrm{EPI} 439494$ & NS & & & & & \\
\hline EPI439495 & PB2 & \multirow{8}{*}{ A/Shanghai/2/2013 } & \multirow{8}{*}{2013} & \multirow{8}{*}{-} & & \\
\hline EPI439501 & $\mathrm{PB} 1$ & & & & & \\
\hline EPI439498 & PA & & & & & \\
\hline EPI439502 & $\mathrm{HA}$ & & & & & \\
\hline EPI439496 & NP & & & & & \\
\hline EPI439500 & NA & & & & & \\
\hline EPI439497 & $M$ & & & & & \\
\hline EPI439499 & NS & & & & & \\
\hline EPI439504 & PB2 & \multirow{8}{*}{ A/Anhui/1/2013 } & \multirow{8}{*}{2013} & \multirow{8}{*}{-} & & \\
\hline EPI439508 & $\mathrm{PB} 1$ & & & & & \\
\hline EPI439503 & PA & & & & & \\
\hline EPI439507 & $\mathrm{HA}$ & & & & & \\
\hline $\mathrm{EPI} 439505$ & NP & & & & & \\
\hline EPI439509 & NA & & & & & \\
\hline EPI439506 & $M$ & & & & & \\
\hline EPI439510 & NS & & & & & \\
\hline EPI440095 & $\mathrm{HA}$ & \multirow{3}{*}{ A/Hangzhou/1/2013 } & \multirow{3}{*}{$2013-03-24$} & \multirow{3}{*}{$\begin{array}{l}\text { Hangzhou Center for Disease } \\
\text { Control and Prevention }\end{array}$} & \multirow{3}{*}{$\begin{array}{l}\text { Hangzhou Center for } \\
\text { Disease Control and } \\
\text { Prevention }\end{array}$} & \multirow{3}{*}{$\begin{array}{l}\text { Li,J; Pan,JC; } \\
\text { Pu,XY; Yu,XF; } \\
\text { Kou,Y; Zhou,YY }\end{array}$} \\
\hline EPI440096 & NA & & & & & \\
\hline EPI440097 & $M$ & & & & & \\
\hline EPI440682 & PB2 & \multirow{8}{*}{$\begin{array}{c}\text { A/Chicken/Shanghai } \\
/ \text { S1053/2013 }\end{array}$} & \multirow{8}{*}{ 2013-04-03 } & \multirow{24}{*}{$\begin{array}{l}\text { Harbin Veterinary Research } \\
\text { Institute }\end{array}$} & \multirow{24}{*}{$\begin{array}{l}\text { Harbin Veterinary } \\
\text { Research Institute }\end{array}$} & \\
\hline EPI440683 & PB1 & & & & & \\
\hline $\mathrm{EPI} 440681$ & PA & & & & & \\
\hline EPI440685 & $\mathrm{HA}$ & & & & & \\
\hline $\mathrm{EPI} 440678$ & NP & & & & & \\
\hline EPI440684 & NA & & & & & \\
\hline EPI440680 & $M$ & & & & & \\
\hline $\mathrm{EPl} 440679$ & NS & & & & & \\
\hline EPI440690 & PB2 & & & & & \\
\hline $\mathrm{EPI} 440691$ & PB1 & & & & & \\
\hline $\mathrm{EPI}_{440689}$ & PA & & & & & \\
\hline $\mathrm{EPI} 440693$ & $\mathrm{HA}$ & $\begin{array}{c}\text { A/Environment/ } \\
\text { Shanghai }\end{array}$ & $2013-04-03$ & & & Huihui Kong \\
\hline EPI440686 & NP & /S1088/2013 & $2013-04-03$ & & & \\
\hline $\mathrm{EPI} 440692$ & $\mathrm{NA}$ & & & & & \\
\hline EPI440688 & $M$ & & & & & \\
\hline $\mathrm{EPI} 440687$ & NS & & & & & \\
\hline EPI440698 & $\mathrm{PB} 2$ & & & & & \\
\hline EPI440699 & PB1 & & & & & \\
\hline EPI440697 & PA & & & & & \\
\hline EPI440701 & $\mathrm{HA}$ & A/Pigeon/Shanghai & $2012-04-02$ & & & \\
\hline $\mathrm{EPI}_{440694}$ & $\mathrm{NP}$ & $/ S_{1069} / 2013$ & $2013-04-02$ & & & \\
\hline EPI440700 & NA & & & & & \\
\hline $\mathrm{EPI} 440696$ & $M$ & & & & & \\
\hline EPI440695 & NS & & & & & \\
\hline
\end{tabular}

We gratefully acknowledge the authors and laboratories for originating and submitting these sequences to the EpiFlu database of the Global Initiative on Sharing All Influenza Data (GISAID); these sequences were the basis for the research presented here.

All submitters of data may be contacted directly via the GISAID website www.gisaid.org 


\section{FIGURE 1}

Phylogenetic analysis of the haemagglutinin (A) and neuraminidase (B) genes of the novel influenza A(H7N9) viruses, China, February-April $2013(\mathrm{n}=7)$

\section{A HA gene}

68 A/mallard/Alberta/34/2001 $\left(\mathrm{H}_{7} \mathrm{~N}_{1}\right)$

A/American green - winged teal/California/44287-305/2007 (H7N6)

A/northern pintail/Alaska/44340-155/2007 $\left(\mathrm{H}_{7} \mathrm{~N}_{3}\right)$

A/blue - winged teal/Ohio/566/2006 ( $\mathrm{H7Ng})$

A/laughing gull/Delaware/42/06 ( $\left.\mathrm{H}_{7} \mathrm{~N}_{3}\right)$

A/American black NC/6412-052/2005 ( $\mathrm{H7N6}$

$91 \mathrm{~A} /$ green winged teal/California/AKS1370/2008 ( $\left.\mathrm{H}_{7} \mathrm{~N}_{3}\right)$

A/environment/Colorado/NWRC186223-18/2007 ( $\mathrm{H} 7 \mathrm{Ng})$

A/mallard/Missouri/10MO0551/2010 ( $\left.\mathrm{H}_{7} \mathrm{~N} 7\right)$

A/northern shoverl/Mississippi/110S145/2011 ( $\mathrm{H} 7 \mathrm{Ng}$ )

A/common goldeneye/Wisconsin/100S4202/2010 (H7N6)

A/American black duck/New Brunswick/00344/2010 (H7N7)

A/Mexico/InDRE7218/2012 ( $\left.\mathrm{B}_{\mathrm{N}} \mathrm{N}\right)$

列

A/mallard/Missouri/220/2010 (

88 A/green - winged teal/California/11275/2008 ( $\left.\mathrm{H}_{7} \mathrm{~N}_{3}\right)$

A/blue - winged teal/Guatemala/CIP049-01/2008 ( $\left.\mathrm{H}_{7} \mathrm{Ng}\right)$

A/mallard/Ohio/11OS2033/2011 (H7N8)
A/ruddy turnstone/Delaware Bay/220/1995 (H7N9)

100

- A/ruddy turnstone/DE/1538/2000 ( $\mathrm{H} 7 \mathrm{Ng}$ )

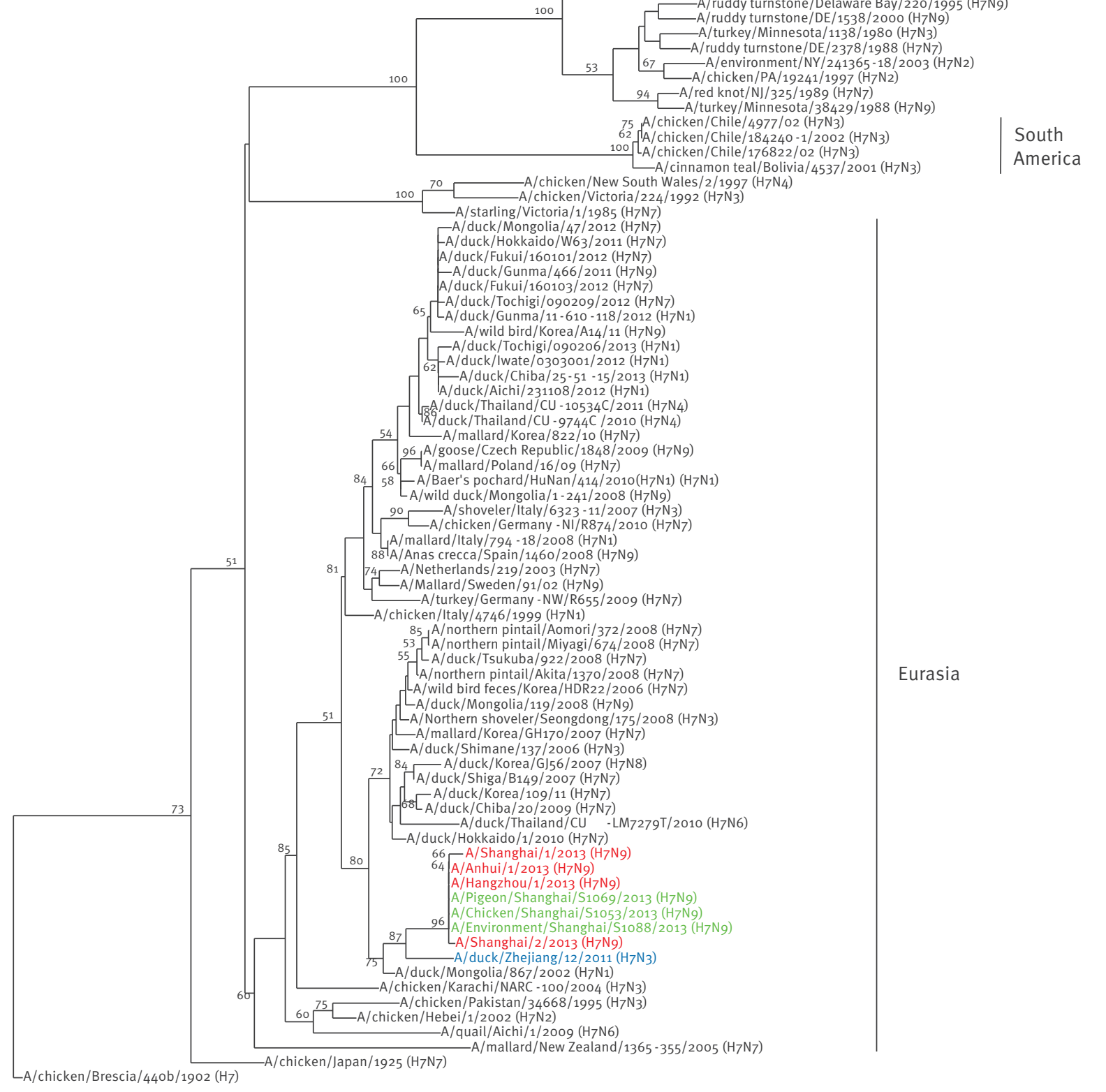

/ruddy turnstone/DE/2378/1988 ( $\mathrm{H} 7 \mathrm{~N} 7$

0.02 ,

HA: haemagglutinin; NA: neuraminidase.

Multiple alignments were constructed by using the CLUSTAL W algorithm. Genetic distances were calculated by using the Kimura's 2-parameter method [26], and phylogenetic trees were constructed by using the neighbour-joining method with bootstrap analyses of 1,000 replicates in CLUSTAL W. Numbers next to nodes indicate bootstrap value percentages (>50\%).

Novel human $\mathrm{H}_{7} \mathrm{~N} 9$ viruses are shown in red; novel $\mathrm{H}_{7} \mathrm{~N}_{9}$ viruses from birds and the environment are shown in green; viruses with the highest similarities to the novel viruses are shown in blue. The HA clade names, North America, South America, and Eurasia, are based on epidemiological studies of $\mathrm{H}_{7}$ viruses $[27,28]$. 


\section{FIGURE 1}

Phylogenetic analysis of the haemagglutinin (A) and neuraminidase (B) genes of the novel influenza A(H7N9) viruses, China, February-April $2013(\mathrm{n}=7)$

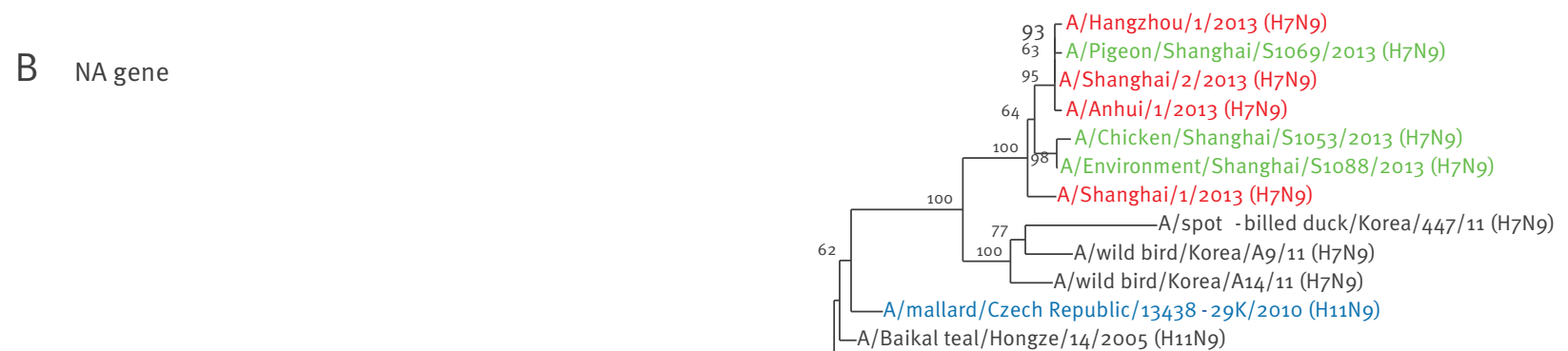

93 A/Hangzhou/1/2013 ( $\mathrm{H} 7 \mathrm{Ng})$

95 A/Shanghai/2/2013 ( $\left.\mathrm{H}_{7} \mathrm{~N} 9\right)$

/Environment/Shanghai/S1088/2013 (H7N9)

A/duck/Vietnam/G17-1/2011 (H11N9)

$\mathrm{A} /$ duck/Vietnam/G17-1/201

A/northern pintail/Aomori/1192/2008 ( $\left.\mathrm{H}_{5} \mathrm{Ng}\right)$

A A/duck/Vietnam/G32/2008 (H11N9)

A/shorebird/Korea/S8/2006 ( $\left.\mathrm{H}_{11 \mathrm{~N} 9}\right)$

A/duck/Chiba/23/2006 (H11N9)

$62 \mathrm{~A} /$ duck/Chiba/11/2006 (H11Ng)

A/duck/Tsukuba/441/2005 ( $\left.\mathrm{H}_{11 \mathrm{~N} 9}\right)$

A/duck/Hokkaido/W245/2004 (H11Ng)

A/duck/Tsukuba/239/2005 ( $\mathrm{H}_{11 \mathrm{~N}}$ )

A/Anas crecca/Spain/1460/2008 (H7Ng)

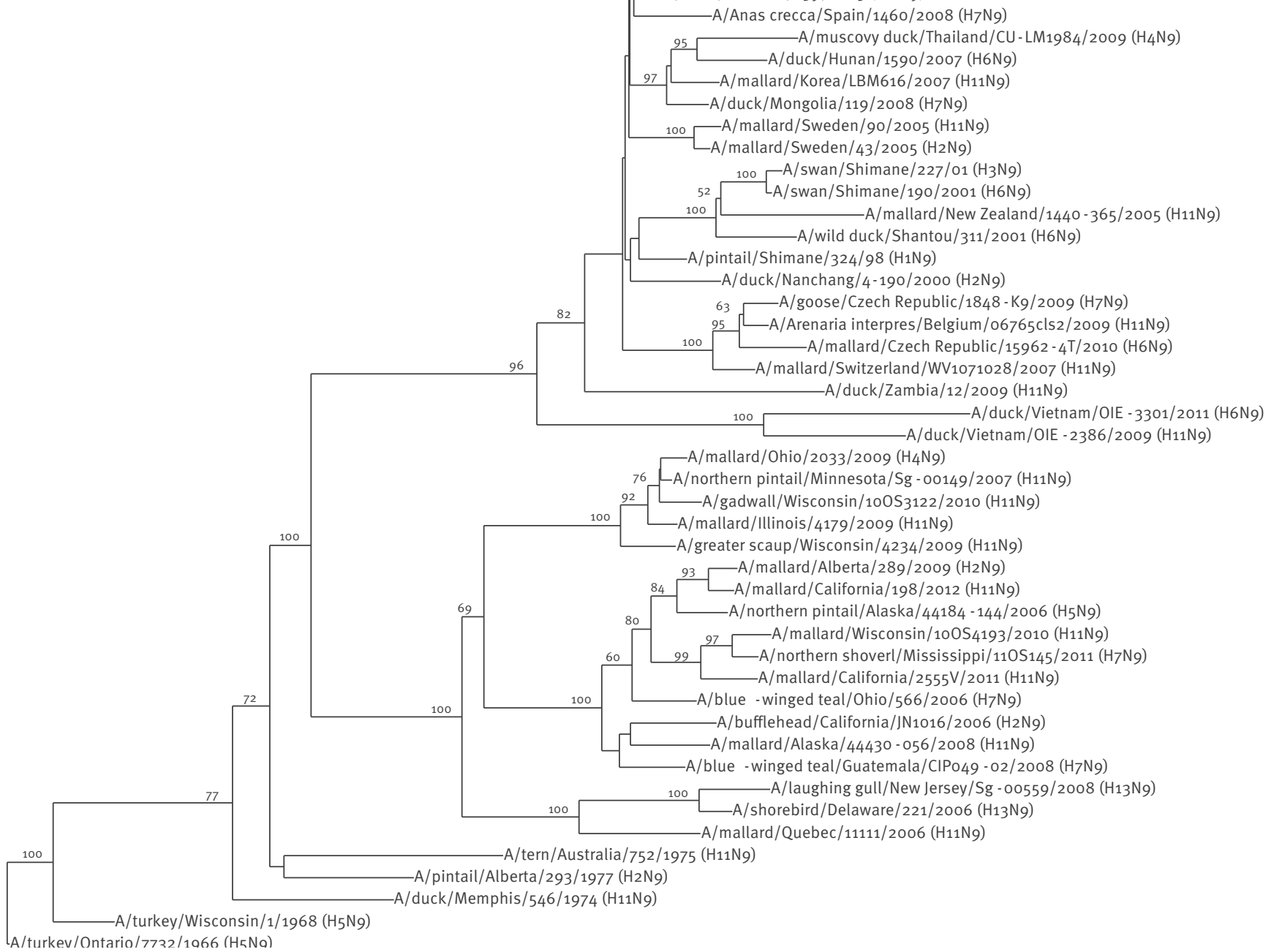

HA: haemagglutinin; NA: neuraminidase.

Multiple alignments were constructed by using the CLUSTAL W algorithm. Genetic distances were calculated by using the Kimura's

2 -parameter method [26], and phylogenetic trees were constructed by using the neighbour-joining method with bootstrap analyses of 1,000 replicates in CLUSTAL W. Numbers next to nodes indicate bootstrap value percentages (>50\%).

Novel human $\mathrm{H}_{7} \mathrm{~N} 9$ viruses are shown in red; novel $\mathrm{H}_{7} \mathrm{~N}_{9}$ viruses from birds and the environment are shown in green; viruses with the highest similarities to the novel viruses are shown in blue. The HA clade names, North America, South America, and Eurasia, are based on epidemiological studies of $\mathrm{H}_{7}$ viruses $[27,28]$. 
TABLE 2

Nucleotide identity of novel influenza A(H7N9) virus genes and their closest relative, China, February-April 2013

\begin{tabular}{|c|c|c|}
\hline Viral gene & Closest influenza virus relative & Nucleotide identity (\%) \\
\hline PB2 & A/brambling/Beijing/16/2012(H9N2) & 99 \\
\hline PB1 & A/chicken/Jiangsu/Q3/2010(H9N2) & 98 \\
\hline PA & A/brambling/Beijing/16/2012(H9N2) & 99 \\
\hline $\mathrm{HA}$ & A/duck/Zhejiang/12/2011(H7N3) & 95 \\
\hline NP & $\mathrm{A} /$ chicken/Zhejiang/611/2011(HgN2) & 98 \\
\hline NA & A/mallard/Czech Republic/13438-29K/2010(H11N9) & 96 \\
\hline M & A/chicken/Zhejiang/607/2011(H9N2) & 98 \\
\hline NS & A/chicken/Dawang/1/2011(H9N2) & 99 \\
\hline
\end{tabular}

HA: haemagglutinin; M: matrix gene; NA: neuraminidase; NP: nucleoprotein; NS: non-structural gene; PA: RNA polymerase acidic subunit; PB1: RNA polymerase basic subunit 1; PB2: RNA polymerase basic subunit 2.

The sequences of the remaining viral genes are closely related $(>97 \%$ identity) to avian influenza $\mathrm{A}\left(\mathrm{H}_{9} \mathrm{~N}_{2}\right)$ viruses, which recently circulated in poultry in Shanghai, Zhejiang, Jiangsu, and neighbouring provinces of Shanghai (Table 2, Figure 2). These findings strongly suggest that the novel influenza $A\left(\mathrm{H}_{7} \mathrm{~N} 9\right)$ viruses are reassortants that acquired their $\mathrm{H}_{7} \mathrm{HA}$ and $\mathrm{N} 9$ NA genes from avian influenza viruses, and their remaining genes from recent influenza $\mathrm{A}\left(\mathrm{H}_{9} \mathrm{~N}_{2}\right)$ poultry viruses (Figure 1, Figure 3, Table 2).

At the nucleotide level, A/Shanghai/2/2013, A/ Anhui/1/2013, and $A /$ Hangzhou/1/2013 share more than $99 \%$ identity and differ by no more than three nucleotides per gene, even though they were isolated in different cities several hundred kilometres apart. On 7 April 2013, the Harbin Veterinary Research Institute deposited the full genome sequences of isolates from a pigeon (A/pigeon/Shanghai/S1069/2013), a chicken (A/chicken/Shanghai/S1053/2013), and an environmental sample (A/environment/Shanghai/S1088/2013) that were collected on 2 and 3 April from a Shanghai market (Table 1). All eight genes of these three isolates are similar to those of A/Shanghai/2/2013 and $A /$ Anhui/1/2013 at the nucleotide level, except for the $\mathrm{PB} 1$ gene of $\mathrm{A} /$ pigeon/Shanghai/S1069/2013, which belongs to a different lineage than the PB1 of the other $\mathrm{H}_{7} \mathrm{~N} 9$ isolates (Figures 1 and 2).

Interestingly, A/Shanghai/1/2013 and A/ Shanghai/2/2013 differ by 52 nucleotides (for example, there are 13 nucleotide and nine amino acid differences in their HA sequences) even though these two cases were identified in the same city and at around the same time. These findings suggest that A/Shanghai/2/2013, A/Anhui/1/2013, A/Hangzhou/1/2013, as well as the viruses from the chicken and the environment, share a closely related source of infection, whereas $\mathrm{A} /$ Shanghai/1/2013 and A/pigeon/Shanghai/S1069/2013 are likely to have originated from other sources.
Highly pathogenic avian influenza viruses are characterised by a series of basic amino acids at the HA cleavage site that enable systemic virus spread. The HA cleavage sequence of the novel influenza $\mathrm{A}\left(\mathrm{H}_{7} \mathrm{~N} 9\right)$ viruses possesses a single basic amino acid (EIPKGR*GL; *indicates the cleavage site), suggesting that these viruses are of low pathogenicity in avian species.

The amino acid sequence of the receptor-binding site (RBS) of HA determines preference for human- or aviantype receptors. At this site, A/Shanghai1/2013 encodes an $\mathrm{A}_{13} 8 \mathrm{~S}^{*}$ mutation ( $\mathrm{H}_{3}$ numbering; Figure 4, Table 3), whereas $A / S h a n g h a i / 2 / 2013, A /$ Anhui/1/2013, the two avian isolates, and the virus from the environmental sample encode G186V and Q226L mutations; any of these three mutations could increase the binding of avian $\mathrm{H}_{5}$ and $\mathrm{H}_{7}$ viruses to human-type receptors [1214]. The finding of mammalian-adapting mutations in the RBS of these novel viruses is cause for concern. The A/Hangzhou/1/2013 isolate encodes isoleucine at position 226, which is found in seasonal influenza $\mathrm{A}\left(\mathrm{H}_{3} \mathrm{~N}_{2}\right)$ viruses.

In addition, all seven influenza $\mathrm{A}\left(\mathrm{H}_{7} \mathrm{~N} 9\right)$ viruses possess a $\mathrm{T}_{16} 6 \mathrm{~A}$ substitution ( $\mathrm{H}_{3}$ numbering; Table 3 ) in $\mathrm{HA}$, which is found in recently circulating $\mathrm{H}_{7}$ viruses; this mutation leads to the loss of an $\mathrm{N}$-glycosylation site at position $158\left(\mathrm{H}_{3}\right.$ numbering; position 149 in $\mathrm{H}_{7}$ numbering), which results in increased virus binding to human-type receptors [15].

Lysine at position 627 of the polymerase $\mathrm{PB} 2$ protein is essential for the efficient replication of avian influenza viruses in mammals [16] and has been detected in highly pathogenic avian influenza $\mathrm{A}\left(\mathrm{H}_{5} \mathrm{~N}_{1}\right)$ viruses and in the influenza $A\left(\mathrm{H}_{7} \mathrm{~N}_{7}\right)$ virus isolated from the fatal case in the Netherlands in 2003 [17]. PB2-627K is rare among avian $\mathrm{H}_{9} \mathrm{~N}_{2} \mathrm{~PB} 2$ proteins (i.e. it has been found in only five of 827 isolates). In keeping with this finding, the avian and environmental influenza $A\left(\mathrm{H}_{7} \mathrm{~N}_{9}\right)$ 


\section{FIGURE 2}

Phylogenetic analysis of the six remaining genes of the novel influenza A(H7N9) viruses, China, February-April 2013 (n=7)

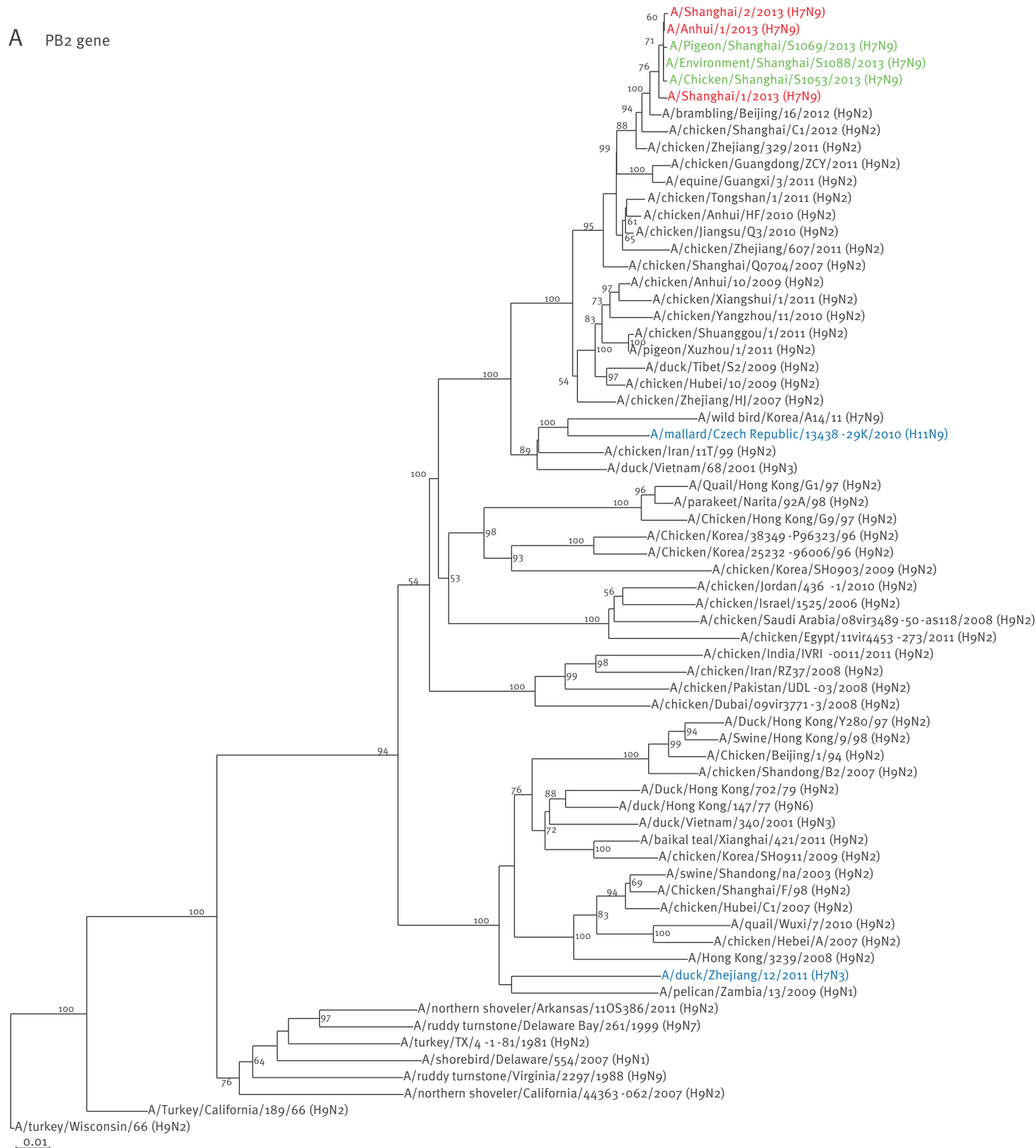

PB2: RNA polymerase basic subunit 2 .

Multiple alignments were constructed by using the CLUSTAL W algorithm. Genetic distances were calculated by using the Kimura's 2-parameter method [26], and phylogenetic trees were constructed by using the neighbour-joining method with bootstrap analyses of 1 ,000 replicates in CLUSTAL W. Numbers next to nodes indicate bootstrap value percentages (>50\%).

The novel human $\mathrm{H}_{7} \mathrm{~N} 9$ viruses are shown in red; novel $\mathrm{H}_{7} \mathrm{~N} 9$ viruses from birds and the environment are shown in green. Influenza viruses whose $\mathrm{HA}$ and NA genes are most closely related to the novel human $\mathrm{H}_{7} \mathrm{~N} 9$ viruses are shown in blue. 


\section{FIGURE 2}

Phylogenetic analysis of the six remaining genes of the novel influenza A(H7N9) viruses, China, February-April 2013 (n=7)

B PB1 gene

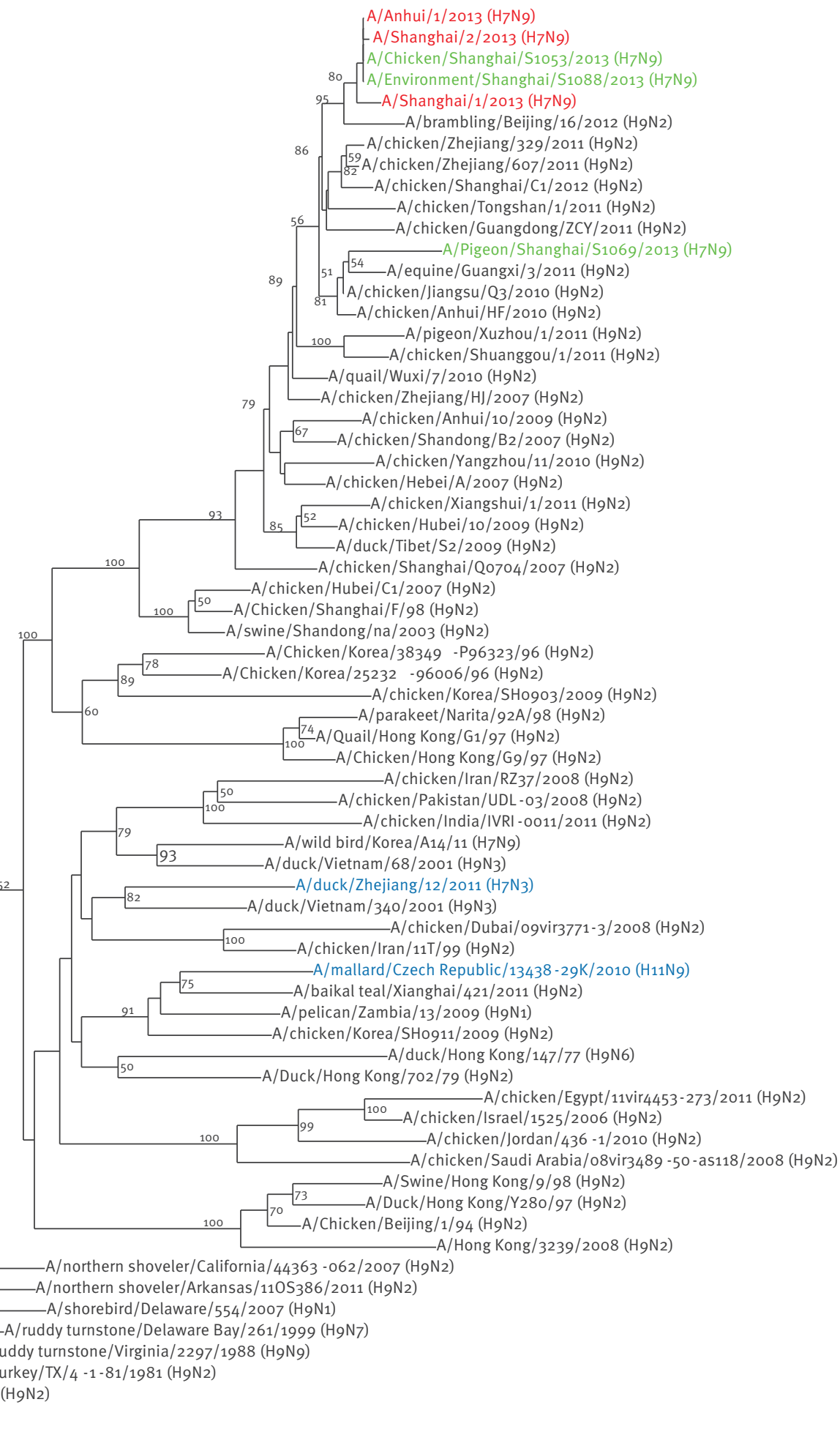

A/turkey/Wisconsin/66 ( $\left.\mathrm{H}_{9} \mathrm{~N}_{2}\right)$

0.01

PB1: RNA polymerase basic subunit 1.

Multiple alignments were constructed by using the CLUSTAL W algorithm. Genetic distances were calculated by using the Kimura's 2-parameter method [26], and phylogenetic trees were constructed by using the neighbour-joining method with bootstrap analyses of 1,000 replicates in CLUSTAL W. Numbers next to nodes indicate bootstrap value percentages (>50\%).

The novel human $\mathrm{H}_{7} \mathrm{~N} 9$ viruses are shown in red; novel $\mathrm{H}_{7} \mathrm{~N} 9$ viruses from birds and the environment are shown in green. Influenza viruses whose HA and NA genes are most closely related to the novel human $\mathrm{H} 7 \mathrm{~N} 9$ viruses are shown in blue. 


\section{FIGURE 2}

Phylogenetic analysis of the six remaining genes of the novel influenza A(H7N9) viruses, China, February-April 2013 (n=7)

C PAgene

A/Anhui/1/2013 ( $\mathrm{H} 7 \mathrm{Ng})$

A/Shanghai/2/2013 ( $\mathrm{H} 7 \mathrm{Ng})$

64 A/Chicken/Shanghai/S1053/2013(H7N9)

57 - A/Pigeon/Shanghai/S1069/2013(H7N9)

80 A/Environment/Shanghai/S1088/2013 (H7Ng)

100 A/Shanghai/1/2013 (H7N9)

A/brambling/Beijing/16/2012 ( $\left.\mathrm{HgN}_{2}\right)$ $\mathrm{A} /$ chicken/Shanghai/C1/2012 ( $\left.\mathrm{HgN}_{2}\right)$

$99 \quad 54 \mathrm{~A} /$ chicken/Zhejiang/607/2011 ( $\left.\mathrm{HgN}_{2}\right)$

-A/equine/Guangxi/3/2011 ( $\mathrm{H} 9 \mathrm{~N} 2^{2}$

77 A/chicken/Anhui/HF/2010 (H9N2)

5 A/chicken/Jiangsu/Q3/2010 (H9N2)

$\mathrm{A} /$ chicken/Guangdong/ZCY/2011
$\mathrm{A} /$ chicken/Xiangshui/1/2011 (H9N2)

-A/quail/Wuxi/7/2010 (H9N2)

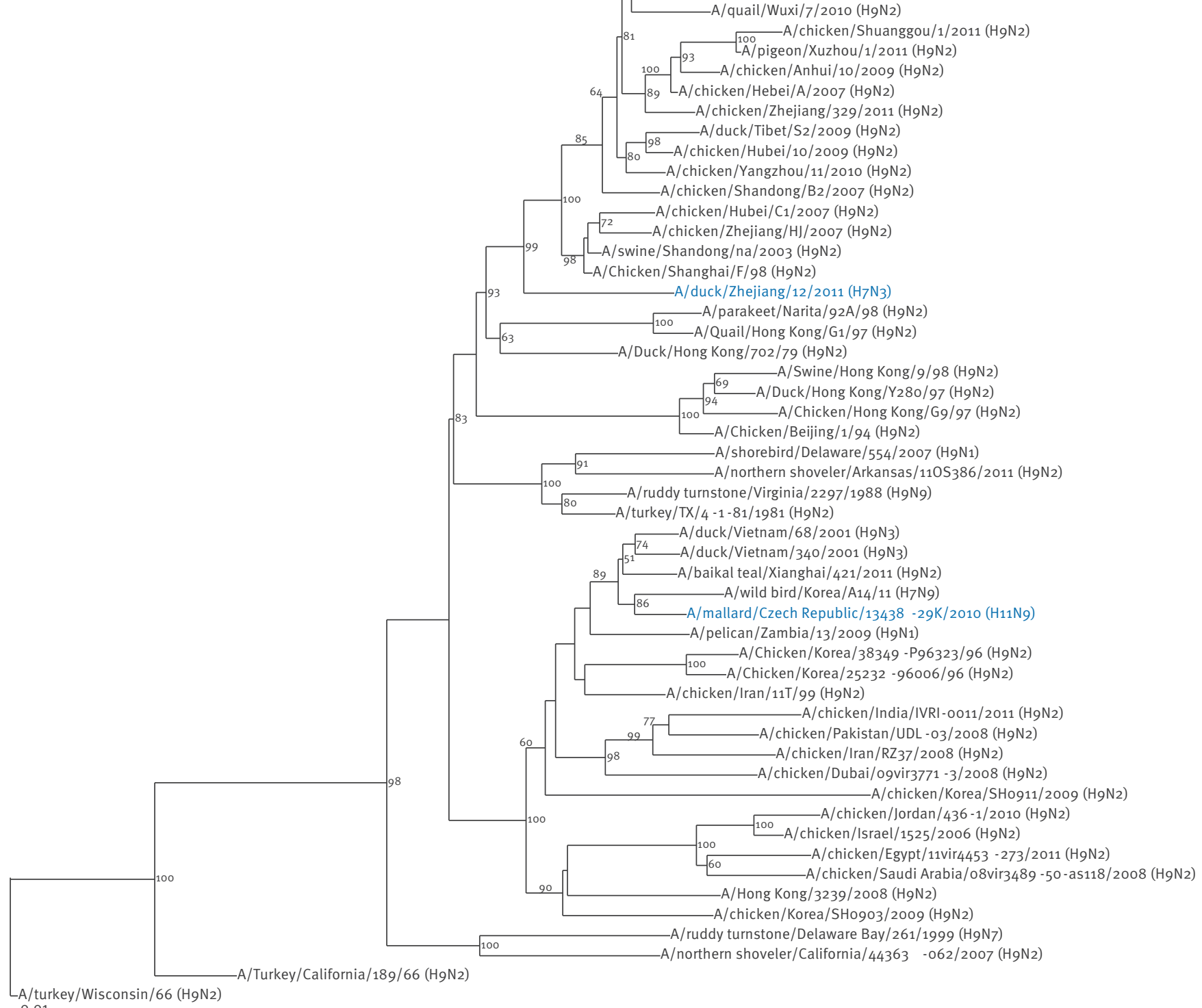

they/Wisconsin/66 ( $\left.\mathrm{H}_{9} \mathrm{~N}_{2}\right)$

0.01

PA: RNA polymerase acidic subunit.

Multiple alignments were constructed by using the CLUSTAL W algorithm. Genetic distances were calculated by using the Kimura's 2-parameter method [26], and phylogenetic trees were constructed by using the neighbour-joining method with bootstrap analyses of 1,000 replicates in CLUSTAL W. Numbers next to nodes indicate bootstrap value percentages (>50\%).

The novel human $\mathrm{H}_{7} \mathrm{~N} 9$ viruses are shown in red; novel $\mathrm{H}_{7} \mathrm{~N} 9$ viruses from birds and the environment are shown in green. Influenza viruses whose HA and NA genes are most closely related to the novel human $\mathrm{H}_{7} \mathrm{~N} 9$ viruses are shown in blue. 


\section{FIGURE 2}

Phylogenetic analysis of the six remaining genes of the novel influenza A(H7N9) viruses, China, February-April 2013 (n=7)

D NP gene

oo A/Chicken/Shanghai/S1053/2013(H7N9)

87 A/Environment/Shanghai/S1088/2013(H7Ng)

100 A/Anhui/1/2013 ( $\mathrm{H} 7 \mathrm{Ng})$

$95 \mathrm{~A} / \mathrm{Shanghai} / 2 / 2013(\mathrm{H} 7 \mathrm{~N} 9)$

-A/Pigeon/Shanghai/S1069/2013 (H7N9)

A/chicken/Zhejiang/611/2011 ( $\left.\mathrm{HgN}_{2}\right)$

- A/chicken/Jiangsu/Q3/2010 ( $\left.\mathrm{H}_{9} \mathrm{~N}_{2}\right)$

A/chicken/Anhui/HF/2010 ( $\left.\mathrm{H}_{9} \mathrm{~N}_{2}\right)$

A/chicken/Zhejiang/329/2011 (H9N2)

A/chicken/Guangdong/ZCY/2011 ( $\left.\mathrm{HgN}_{2}\right)$

A/brambling/Beijing/16/2012 ( $\left.\mathrm{H}_{9} \mathrm{~N} 2\right)$ 58 A/chicken/Xiangshui/1/2011 ( $\left.\mathrm{HgN}_{2}\right)$

$-\mathrm{A}-\mathrm{s} /$ chicken/Tongshan/1/2011 $\left(\mathrm{HgN}_{2}\right)$

$82 \quad$ A/quail/Wuxi/7/2010 (HgN2)

$54 \quad$ A/duck/Tibet/S2/2009 ( $\mathrm{HgN} 2)$

A/chicken/Hubei/10/2009 ( $\left.\mathrm{H}_{9} \mathrm{~N}_{2}\right)$

A/chicken/Zhejiang/HJ/2007 ( $\mathrm{HgN}_{2}$ )

$50 \quad 98-\mathrm{A}^{\mathrm{A} / \text { chicken/Shuanggou/1/2011 (H9N2) }}$

$100 \mathrm{~A} /$ chicken/Yangzhou/11/2010 (HgN2)

A/chicken/Anhui/10/2009 (H9N2)

- A/chicken/Hebei/A/2007 ( $\left.\mathrm{HgN}_{2}\right)$

$\mathrm{A} /$ chicken/Shandong/B2/2007 ( $\left.\mathrm{HgN}_{2}\right)$ A/chicken/Shanghai/Q0704/2007 ( $\left.\mathrm{HgN}_{2}\right)$

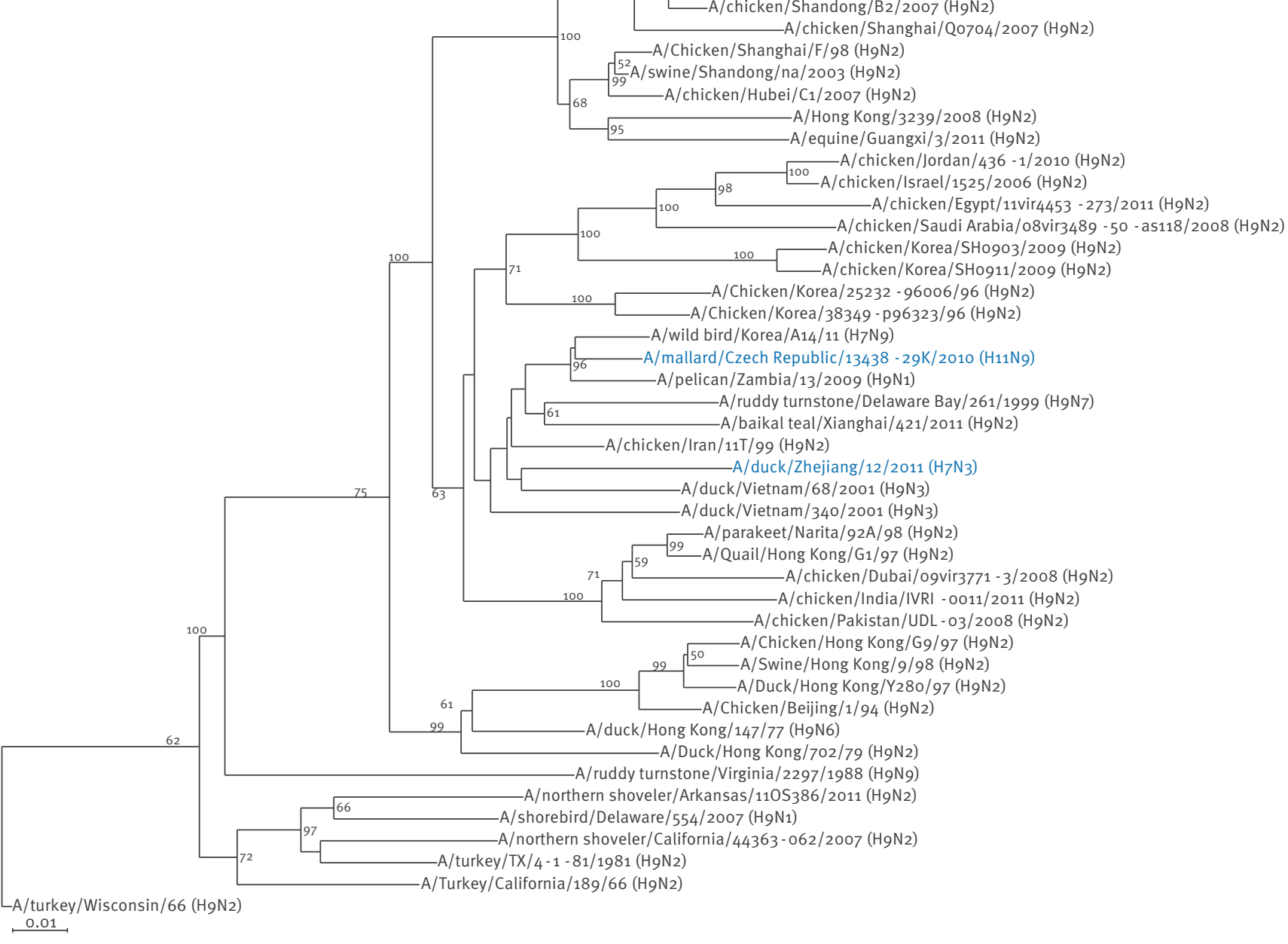

NP: nucleoprotein.

Multiple alignments were constructed by using the CLUSTAL W algorithm. Genetic distances were calculated by using the Kimura's 2-parameter method [26], and phylogenetic trees were constructed by using the neighbour-joining method with bootstrap analyses of 1,000 replicates in CLUSTAL W. Numbers next to nodes indicate bootstrap value percentages (>50\%).

The novel human $\mathrm{H}_{7} \mathrm{~N} 9$ viruses are shown in red; novel $\mathrm{H}_{7} \mathrm{~N} 9$ viruses from birds and the environment are shown in green. Influenza viruses whose HA and NA genes are most closely related to the novel human $\mathrm{H}_{7} \mathrm{~N} 9$ viruses are shown in blue. 


\section{FIGURE 2}

Phylogenetic analysis of the six remaining genes of the novel influenza A(H7N9) viruses, China, February-April 2013 (n=7)

E M gene

A/Chicken/Shanghai/S1053/2013 ( H7N9)

-A/Environment/Shanghai/S1088/2013 (H7Ng)

A/Anhui/1/2013 (H7N9)

A/Shanghai/2/2013 ( $\left.\mathrm{H}_{7} \mathrm{Ng}\right)$

66 A/Hangzhou/1/2013 ( $\mathrm{H} 7 \mathrm{~N} 9)$

99 A/Shanghai/1/2013 (H7N9)

A/Pigeon/Shanghai/S1069/2013 (H7N9)

$57 \_$A/brambling/Beijing/16/2012 ( $\left.\mathrm{HgN}_{2}\right)$

${ }^{57}$ A/chicken/Zhejiang/329/2011 (H9N2)

$\mathrm{A} /$ chicken/Anhui/HF/2010 ( $\left.\mathrm{H}_{9 \mathrm{~N}}\right)$

A/chicken/Shanghai/C1/2012 ( $\left.\mathrm{H}_{9} \mathrm{~N}_{2}\right)$

A/chicken/Yangzhou/11/2010 (HgN2)

-A/chicken/Zhejiang/607/2011 ( $\left.\mathrm{HgN}_{2}\right)$

$\mathrm{A} /$ chicken/Tongshan/1/2011 $(\mathrm{HgN} 2)$

${ }_{A}^{69} /$ chicken/Jiangsu/Q3/2010 ( $\left.\mathrm{H}_{9} \mathrm{~N}_{2}\right)$

-A/equine/Guangxi/3/2011 ( $\left.\mathrm{HgN}_{2}\right)$

A/pigeon/Xuzhou/1/2011 ( $\left.\mathrm{HgN}_{2}\right)$

${ }^{87} \mathrm{~A} /$ chicken/Shuanggou/1/2011 ( $\left.\mathrm{HgN}_{2}\right)$

A/quail/Wuxi/7/2010 (H9N2)

$90 \mathrm{~A} /$ chicken/Guangdong/ZCY/2011 $\left(\mathrm{H}_{9} \mathrm{~N}_{2}\right)$

A/chicken/Xiangshui/1/2011 ( $\left.\mathrm{HgN}_{2}\right)$

${ }_{96} \mathrm{~A} /$ chicken/Anhui/10/2009 ( $\left.\mathrm{HgN}_{2}\right)$

${ }_{\mathrm{A}}^{96}$ /chicken/Hubei/10/2009 ( $\left.\mathrm{HgN}_{2}\right)$

72 A4/chicken/Hebei/A/2007 ( $\left.\mathrm{HgN}_{2}\right)$

A/chicken/Zhejiang/HJ/2007 ( $\mathrm{HgN}_{2}$

A/duck/Tibet/S2/2009 ( $\left.\mathrm{H}_{9} \mathrm{~N} 2\right)$

A/Hong Kong/3239/2008 ( $\left.\mathrm{H}_{9} \mathrm{~N}_{2}\right)$

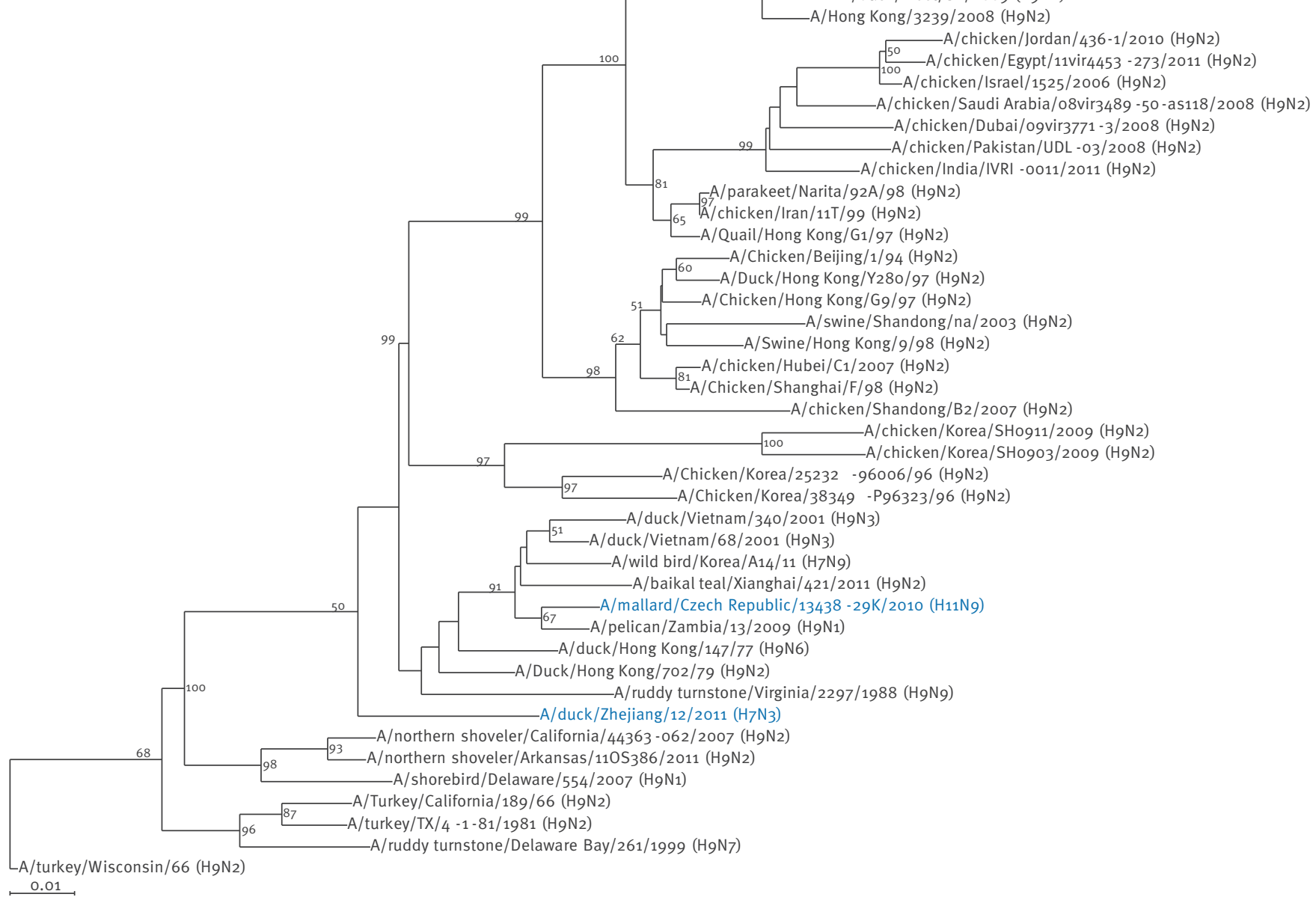

M: matrix gene.

Multiple alignments were constructed by using the CLUSTAL W algorithm. Genetic distances were calculated by using the Kimura's 2-parameter method [26], and phylogenetic trees were constructed by using the neighbour-joining method with bootstrap analyses of 1,000 replicates in CLUSTAL W. Numbers next to nodes indicate bootstrap value percentages (>50\%).

The novel human $\mathrm{H}_{7} \mathrm{~N} 9$ viruses are shown in red; novel $\mathrm{H}_{7} \mathrm{~N} 9$ viruses from birds and the environment are shown in green. Influenza viruses whose HA and NA genes are most closely related to the novel human $\mathrm{H}_{7} \mathrm{~N} 9$ viruses are shown in blue. 


\section{FIGURE 2}

Phylogenetic analysis of the six remaining genes of the novel influenza A(H7N9) viruses, China, February-April 2013 (n=7)

F NS gene

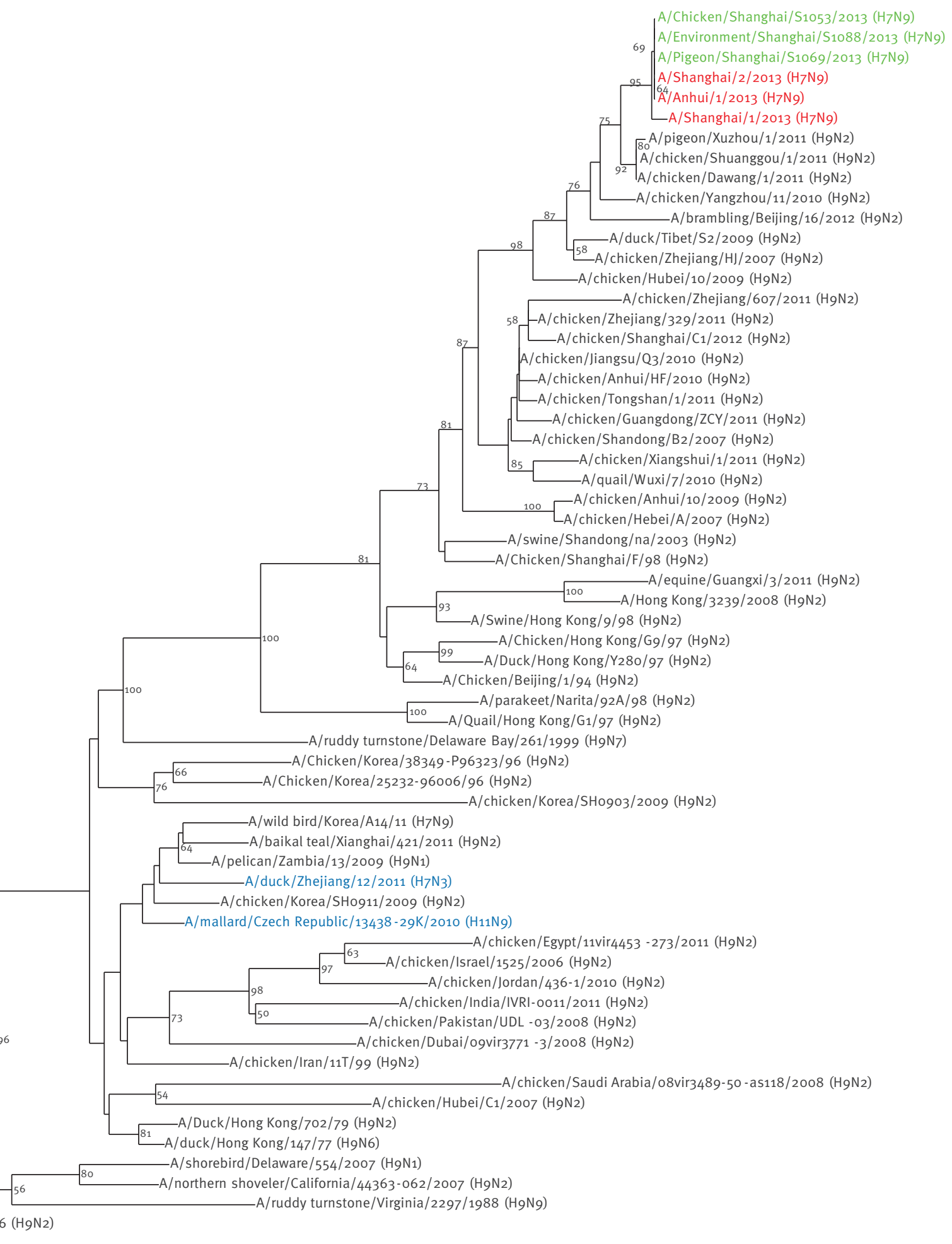

A/turkey/Wisconsin/66 ( $\left.\mathrm{H}_{9} \mathrm{~N} 2\right)$

$n n 1$

NS: non-structural gene.

Multiple alignments were constructed by using the CLUSTAL W algorithm. Genetic distances were calculated by using the Kimura's 2-parameter method [26], and phylogenetic trees were constructed by using the neighbour-joining method with bootstrap analyses of 1,000 replicates in CLUSTAL W. Numbers next to nodes indicate bootstrap value percentages (>50\%).

The novel human $\mathrm{H}_{7} \mathrm{~N} 9$ viruses are shown in red; novel $\mathrm{H}_{7} \mathrm{~N} 9$ viruses from birds and the environment are shown in green. Influenza viruses whose HA and NA genes are most closely related to the novel human $\mathrm{H}_{7} \mathrm{~N} 9$ viruses are shown in blue. 

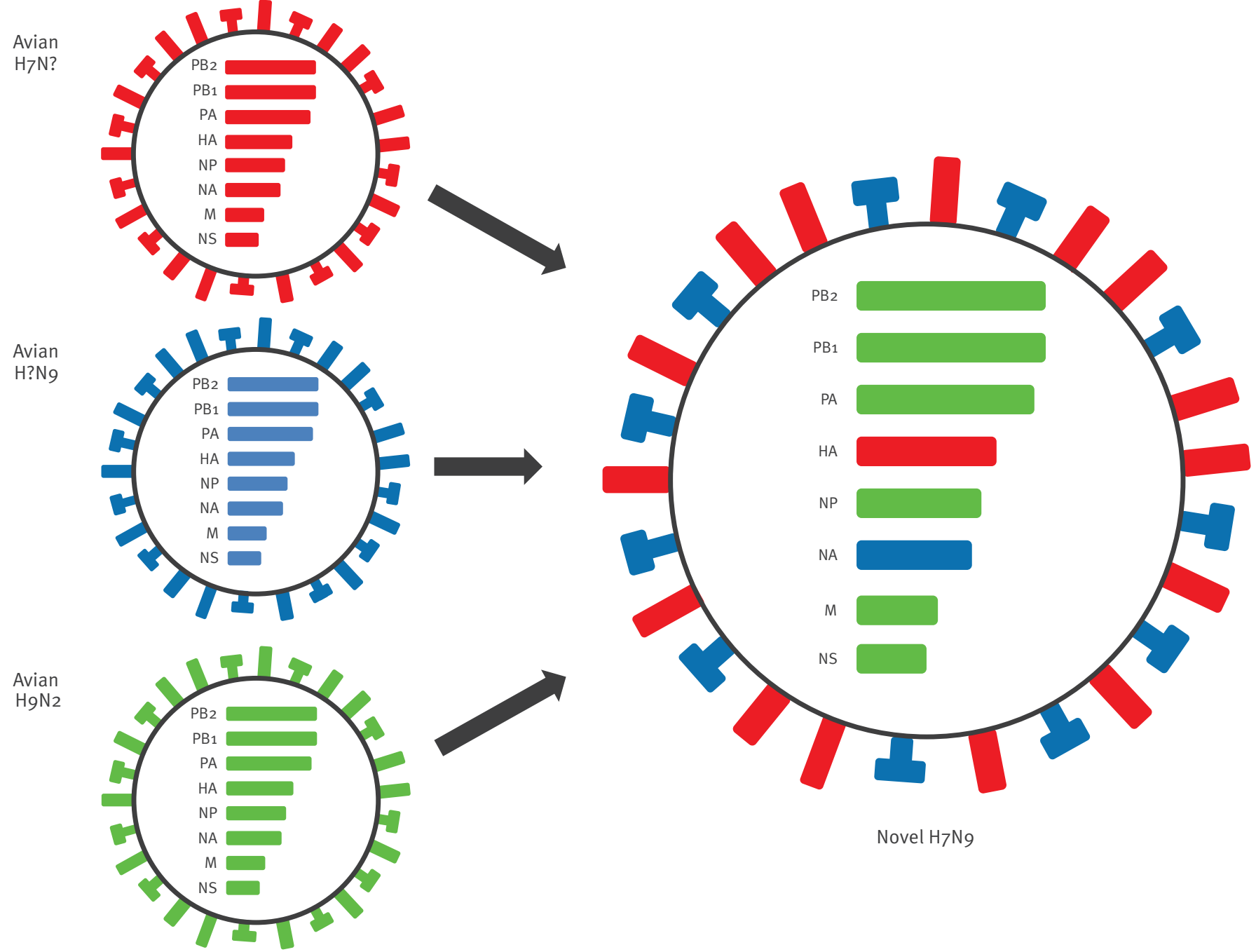

Novel $\mathrm{H}_{7} \mathrm{~N} 9$

HA: haemagglutinin; NA: neuraminidase.

The novel influenza $\mathrm{A}\left(\mathrm{H}_{7} \mathrm{~N}\right.$ ) ) viruses are likely to have acquired their $\mathrm{HA}$ gene from an avian $\mathrm{H}_{7}$ virus of unknown NA subtype, their NA gene from an avian $\mathrm{N} 9$ virus of unknown HA subtype, and their remaining six viral segments from avian $\mathrm{H} 9 \mathrm{~N} 2$ viruses circulating in poultry.

viruses analysed here encode PB2-627E. By contrast, all four human $\mathrm{H}_{7} \mathrm{~N} 9$ viruses analysed here encode PB2-627K (Table 3).

Antiviral compounds are the first line of defense against novel influenza viruses until vaccines become available. All seven novel influenza $A\left(\mathrm{H}_{7} \mathrm{N9}\right)$ viruses sequenced to date encode the $\mathrm{S}_{31 \mathrm{~N}}$ substitution in the viral ion channel M2 (encoded by the M segment) (Table 3), which confers resistance to ion channel inhibitors $[18,19]$. Based on the sequences of their NA proteins, all $\mathrm{H}_{7} \mathrm{~N}_{9}$ viruses analysed here, with the exception of A/Shanghai/1/2013, should be sensitive to neuraminidase inhibitors (Table 3). However, the R294K mutation in the NA protein of $A / S h a n g h a i / 1 / 2013$ is known to confer resistance to NA inhibitors in $\mathrm{N}_{2}$ and N9 subtype viruses [20], and is therefore of great concern.

All $\mathrm{H}_{7} \mathrm{~N} 9$ viruses encode a deletion at positions 69-73 of the NA stalk region (Table 3), which is reported to occur upon virus adaptation to terrestrial birds. This finding suggests that the novel $\mathrm{H}_{7} \mathrm{~N} 9$ viruses (or their ancestor) may have circulated in terrestrial birds before infecting humans. Moreover, this deletion is associated with increased virulence in mammals [21].

The influenza $A$ virus $P B 1-F 2$ protein (encoded by the $\mathrm{PB} 1$ segment) is also associated with virulence. The available sequences indicate that the $\mathrm{H}_{7} \mathrm{~N}_{9} \mathrm{~PB}_{1}$ genes of all of the human viruses encode a full-length PB1-F2 of 90 amino acids, but lack the N66S mutation that is 


\section{FIGURE 4}

Amino acid changes in the three novel influenza A(H7N9) viruses that may affect their receptor-binding properties, China, February-April $2013(\mathrm{n}=7)$

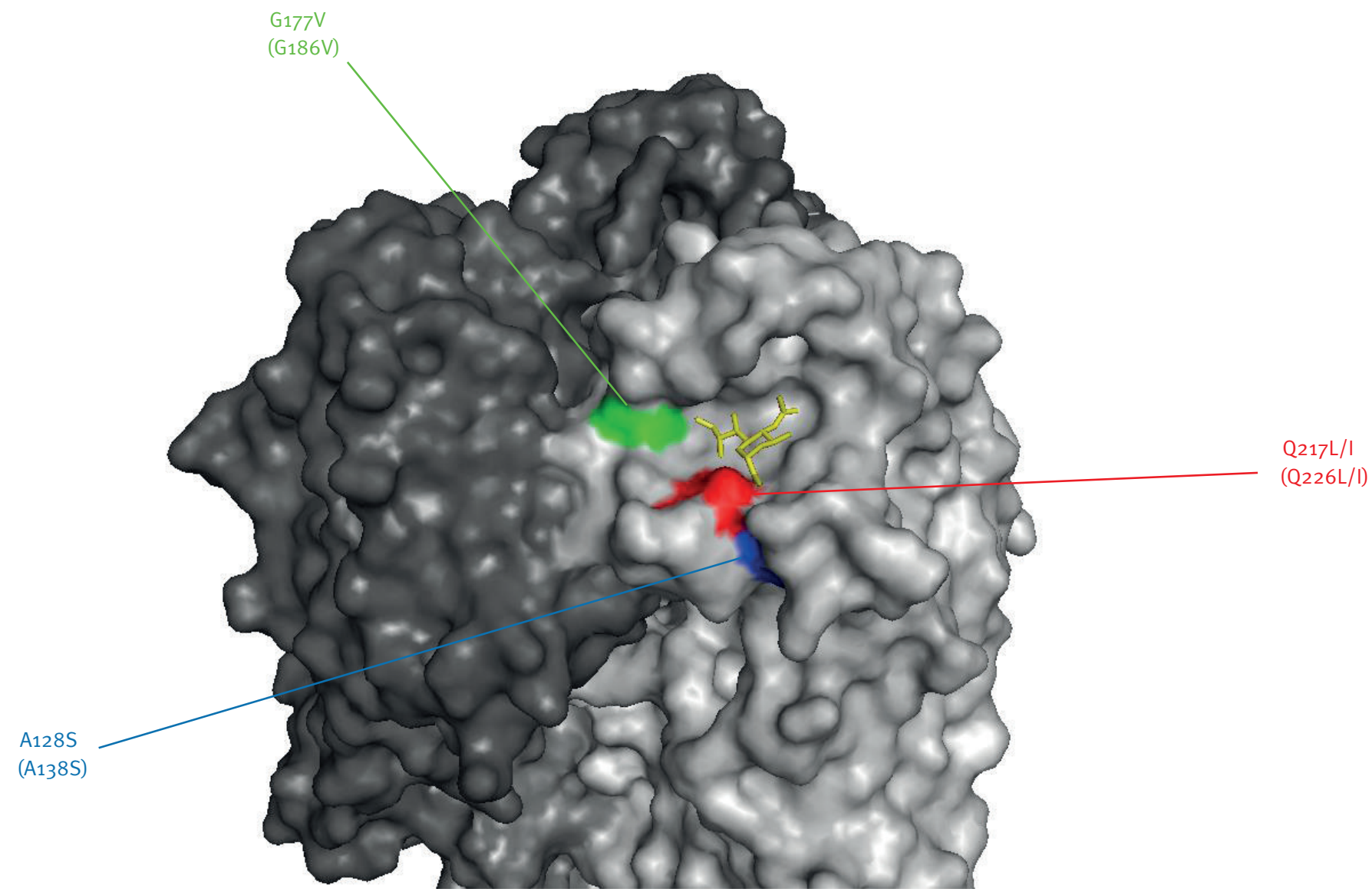

H7 numbering

(H3 numbering)

Shown is the three-dimensional structure of three monomers (light and dark gray) of the influenza $A(H 7 N 7)$ virus $(A / N e t h e r l a n d s / 219 / 2003)$ haemagglutinin (accession code 4DJ8). Also shown is the part of 6'-sialyl-N-acetyllactosamine (a sialyloligosaccharide) to which human viruses bind preferentially (yellow). Indicated are amino acid changes in the $\mathrm{H} 7 \mathrm{~N} 9$ virus haemagglutinin protein at positions known to increase binding to human-type receptors.

associated with the increased pathogenicity of the 1918 pandemic virus and the highly pathogenic avian influenza $A\left(\mathrm{H}_{5} \mathrm{~N}_{1}\right)$ viruses [22]. Interestingly, the pigeon isolate encodes a truncated $\mathrm{PB}_{1}-\mathrm{F}_{2}$ of only 25 amino acids; the significance of this truncation is unknown.

The NS1 protein (encoded by the NS segment) is an interferon antagonist with several functions in the viral life cycle. All available $\mathrm{H}_{7} \mathrm{~N}_{9} \mathrm{NS}_{1}$ sequences lack the C-terminal PDZ domain-binding motif; the lack of the PDZ domain-binding motif may attenuate these viruses in mammals [23].

Other amino acids in the NS1 and matrix ( $\mathrm{M}_{1}$; encoded by the $M$ segment) proteins of the novel viruses are also associated with increased virulence (Table 3 ) [24.25]. However, these amino acids are found in many avian influenza viruses, and therefore, their significance for the biological properties of the novel influenza $A\left(\mathrm{H}_{7} \mathrm{~N} 9\right)$ viruses is currently unclear.

In conclusion, we here present a biological evaluation of the sequences of the avian influenza $A\left(\mathrm{H}_{7} \mathrm{Ng}\right)$ viruses that caused fatal human infections in China. These viruses possess several characteristic features of mammalian influenza viruses, which are likely to contribute to their ability to infect humans and raise concerns regarding their pandemic potential.

*Authors' correction:

The mutation $\mathrm{A}_{13} 8 \mathrm{~S}$ was erroneously written as $\mathrm{S} 138 \mathrm{~A}$ in the original publication. This mistake was corrected on 13 April 2013 


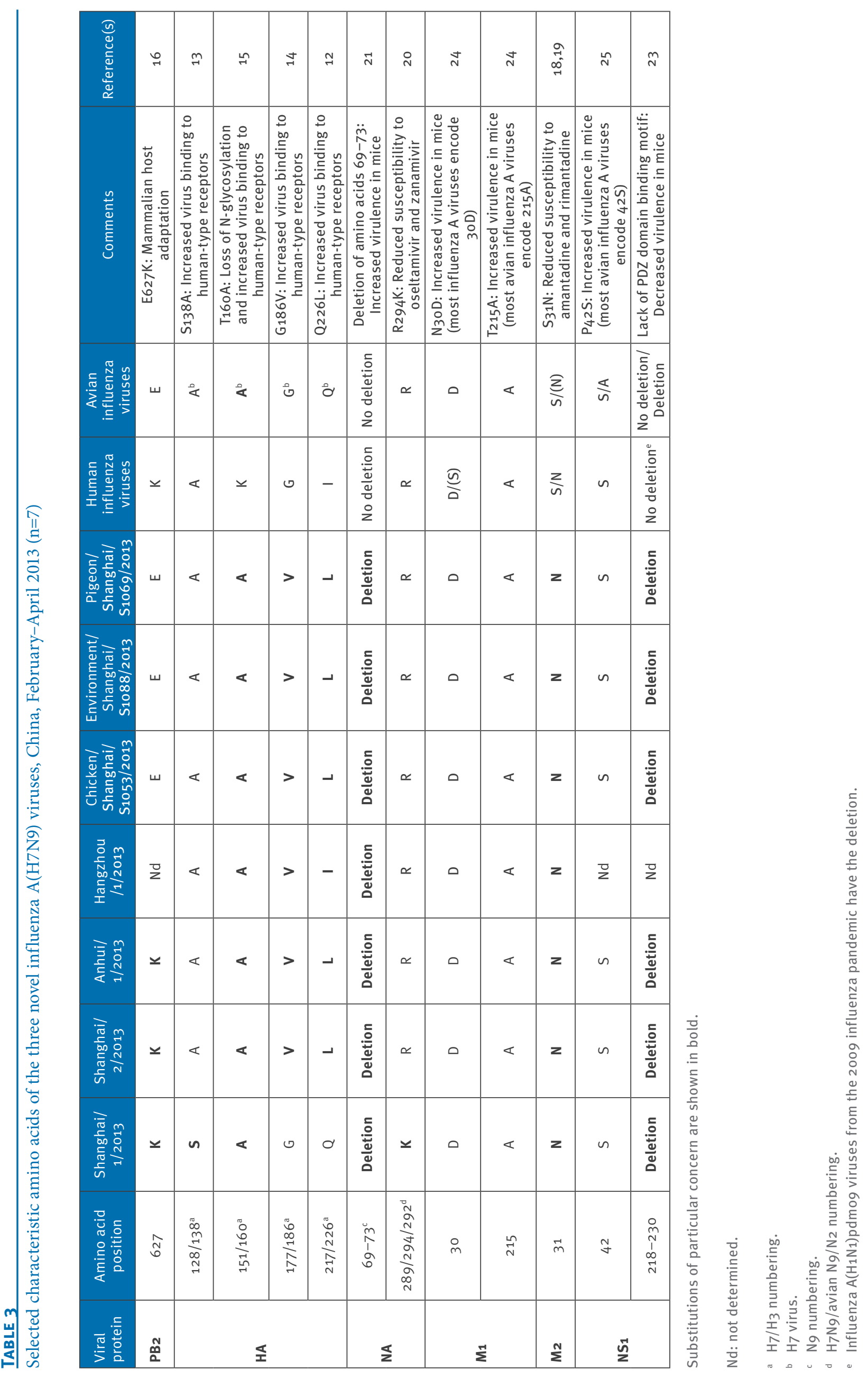




\section{Acknowledgements}

We are grateful to Dr. Shu Yuelong, Chinese National Influenza Center, Chinese Center for Disease Control and Prevention, Beijing, China, for his rapid publication of the entire gene sequence data of $A\left(\mathrm{H}_{7} \mathrm{~N} 9\right)$ viruses isolated from human cases in China, and also for his information sharing and advice to this study. We also thank Susan Watson for scientific editing. This work was supported by Grants-in-Aid for Pandemic Influenza Research (TK, SF, HX, and MT) and Grant-in-Aid for Specially Promoted Research (MT) from the Ministry of Health, Labour and Welfare, Japan, by the NIAIDfunded Center for Research on Influenza Pathogenesis (CRIP, HHSN266200700010C)(YK), by a Grant-in-Aid for Specially Promoted Research, by the Japan Initiative for Global Research Network on Infectious Diseases from the Ministry of Education, Culture, Sports, Science, and Technology, Japan (YK), and by ERATO, Japan (YK).

\section{Authors contributions}

Designed the analyses: TK, SF, ET, SY, GN, YK, MT. Analysed and interpreted data: TK, SF, ET, HX, SY, YU, GN, YK, MT. Drafted the article: TK, SF. Revised the article: ET, GN, TS, YK, MT.

\section{Conflict of interest}

None declared.

This manuscript was accepted on 11 April 2013 and published online on 12 April 2013

\section{References}

1. World Health Organization (WHO)/Global Influenza Programme Cumulative number of confirmed human cases for avian influenza $\mathrm{A}\left(\mathrm{H}_{5} \mathrm{~N}_{1}\right)$ reported to WHO, 2003-2013. Geneva: WHO: 12 Mar 2013. Available from: http://www.who.int/influenza/ human_animal_interface/EN_GIP_20130312CumulativeNumbe rH 5 Nicases.pdf

2. Campbell CH, Webster RG, Breese SS Ir. Fowl plague virus from man. J Infect Dis. 1970;122(6):513-6. http://dx.doi.org/10.1093/ infdis/122.6.513. PMid: 5489075 .

3. Centers for Disease Control and Prevention (CDC). Update: influenza activity-United States and worldwide, 200304 season, and composition of the 2004-05 influenza vaccine. MMWR Morb Mortal Wkly Rep. 2004;53(25):547-52. PMid:15229411.

4. Editorial team. Avian influenza $\mathrm{A} /\left(\mathrm{H}_{7} \mathrm{~N}_{2}\right)$ outbreak in the United Kingdom. Euro Surveill. 2007;12(22): : pii=3206. Available from: http://www.eurosurveillance.org/ViewArticle. aspx?Articleld $=3206$

5. Fouchier RA, Schneeberger PM, Rozendaal FW, Broekman $J M$, Kemink SA, Munster V, et al. Avian influenza A virus $(\mathrm{H} 7 \mathrm{~N} 7)$ associated with human conjunctivitis and a fatal case of acute respiratory distress syndrome. Proc Natl Acad Sci U S A. 2004;101(5):1356-61. http://dx.doi.org/10.1073/ pnas.0308352100. PMid:14745020 PMCid:337057.

6. Hirst M, Astell CR, Griffith M, Coughlin SM, Moksa M, Zeng T, et al. Novel avian influenza $\mathrm{H}_{7} \mathrm{~N}_{3}$ strain outbreak, British Columbia. Emerg Infect Dis. 2004:10(12):2192-5. http://dx.doi. org/10.3201/eid1012.040743. PMid:15663859. PMCid:3323367.

7. Koopmans M, Wilbrink B, Conyn M, Natrop G, van der Nat H, Vennema $\mathrm{H}$, et al. Transmission of $\mathrm{H}_{7} \mathrm{~N} 7$ avian influenza A virus to human beings during a large outbreak in commercial poultry farms in the Netherlands. Lancet. 2004;363(9409):587-93. http://dx.doi.org/10.1016/S0140-6736(04)15589-X.

8. Kurtz J, Manvell RJ, Banks J. Avian influenza virus isolated from a woman with conjunctivitis. Lancet. 1996;348(9031):901-2. http://dx.doi.org/10.1016/S0140-6736(05)64783-6.

9. Nguyen-Van-Tam JS, Nair P, Acheson P, Baker A, Barker M, Bracebridge S, et al. Outbreak of low pathogenicity $\mathrm{H}_{7} \mathrm{~N}_{3}$ avian influenza in UK, including associated case of human conjunctivitis. Euro Surveill. 2006;11(18): pii=2952. Available from: http://www.eurosurveillance.org/ViewArticle. aspx?Articleld=2952. PMid: 16816456

10. Taylor HR, Turner AJ. A case report of fowl plague keratoconjunctivitis. Br J Ophthalmol. 1977;61(2):86-8. http:// dx.doi.org/10.1136/bjo.61.2.86.
11. Tweed SA, Skowronski DM, David ST, Larder A, Petric M, Lees W, et al. Human Illness from Avian Influenza $\mathrm{H}_{7} \mathrm{~N}_{3}$, British Columbia. Emerg Infect Dis. 2004:10(12):2196-9. http://dx.doi. org/10.3201/eid1012.040961. PMid:15663860 PMCid:3323407.

12. Srinivasan K, Raman R, Jayaraman A, Viswanathan K, Sasisekharan R. Quantitative description of glycan-receptor binding of influenza A virus $\mathrm{H} 7$ hemagglutinin. PLoS One. 2013;8(2):e49597. http://dx.doi.org/10.1371/journal. pone.0049597. PMid:23437033 PMCid:3577880.

13. Nidom CA, Takano R, Yamada S, Sakai-Tagawa Y, Daulay $\mathrm{S}$, Aswadi D, et al. Influenza $A\left(\mathrm{H}_{5} \mathrm{~N}_{1}\right)$ viruses from pigs, Indonesia. Emerg Infect Dis. 2010;16(10):1515-23. http://dx.doi. org/10.3201/eid1610.100508. PMid:20875275. PMCid:3294999.

14. Yang H, Chen LM, Carney PJ, Donis RO, Stevens J. Structures of receptor complexes of a North American $\mathrm{H}_{7} \mathrm{~N}_{2}$ influenza hemagglutinin with a loop deletion in the receptor binding site. PLoS Pathog. 2010;6(9):e1001081. http://dx.doi.org/10.1371/ journal.ppat.1001081 PMid:20824086 PMCid:2932715.

15. Wang W, Lu B, Zhou H, Suguitan AL Jr, Cheng X, Subbarao $\mathrm{K}$, et al. Glycosylation at $158 \mathrm{~N}$ of the hemagglutinin protein and receptor binding specificity synergistically affect the antigenicity and immunogenicity of a live attenuated $\mathrm{H}_{5} \mathrm{~N}_{1}$ A/Vietnam/1203/2004 vaccine virus in ferrets. J Virol. 2010;84(13):6570-7. http://dx.doi.org/10.1128/JVI.00221-10. PMid:20427525 PMCid:2903256.

16. Hatta M, Gao P, Halfmann P, Kawaoka Y. Molecular basis for high virulence of Hong Kong $\mathrm{H}_{5} \mathrm{~N}_{1}$ influenza $A$ viruses. Science. 2001;293(5536):1840-2. http://dx.doi.org/10.1126/ science.1062882. PMid:11546875.

17. Munster VJ, de Wit E, van Riel D, Beyer WE, Rimmelzwaan GF, Osterhaus AD, et al. The molecular basis of the pathogenicity of the Dutch highly pathogenic human influenza $\mathrm{A} \mathrm{H} 7 \mathrm{~N} 7$ viruses. J Infect Dis. 2007;196(2):258-65. http://dx.doi. org/10.1086/518792. PMid:17570113.

18. Hay AJ, Wolstenholme AJ, Skehel JJ, Smith MH. The molecular basis of the specific anti-influenza action of amantadine. EMBO J. 1985;4(11):3021-4. PMid:4065098 PMCid:554613.

19. Pinto LH, Holsinger LJ, Lamb RA. Influenza virus $M_{2}$ protein has ion channel activity. Cell. 1992;69(3):517-28. http://dx.doi. org/10.1016/0092-8674(92)90452-I.

20. McKimm-Breschkin JL, Sahasrabudhe A, Blick TJ, McDonald $M$, Colman PM, Hart GJ, et al. Mutations in a conserved residue in the influenza virus neuraminidase active site decreases sensitivity to Neu5Aczen-derived inhibitors. J Virol. 1998;72(3):2456-62. PMid:9499107. PMCid:109546.

21. Matsuoka Y, Swayne DE, Thomas C, Rameix-Welti MA, Naffakh $\mathrm{N}$, Warnes $\mathrm{C}$, et al. Neuraminidase stalk length and additional glycosylation of the hemagglutinin influence the virulence of influenza $\mathrm{H}_{5} \mathrm{~N}_{1}$ viruses for mice. J Virol. 2009;83(9):4704 8. http://dx.doi.org/10.1128/JVI.01987-08. PMid:19225004 PMCid:2668507.

22. Conenello GM, Zamarin D, Perrone LA, Tumpey T, Palese P. A single mutation in the PB1-F2 of $\mathrm{H}_{5} \mathrm{~N}_{1}(\mathrm{HK} / 97)$ and 1918 influenza A viruses contributes to increased virulence. PLoS Pathog. 2007;3(10):1414-21. http://dx.doi.org/10.1371/journal. ppat.0030141. PMid:17922571. PMCid:2000966.

23. Jackson D, Hossain MJ, Hickman D, Perez DR, Lamb RA. A new influenza virus virulence determinant: the NS1 protein four C-terminal residues modulate pathogenicity. Proc Natl Acad Sci U S A. 2008;105(11):4381-6. http://dx.doi.org/10.1073/ pnas.0800482105. PMid:18334632 PMCid:2393797.

24. Fan S, Deng G, Song J, Tian G, Suo Y, Jiang Y, et al. Two amino acid residues in the matrix protein $M_{1}$ contribute to the virulence difference of $\mathrm{H}_{5} \mathrm{~N} 1$ avian influenza viruses in mice. Virology. 2009;384(1):28-32. http://dx.doi.org/10.1016/j. virol.2008.11.044. PMid:19117585.

25. Jiao P, Tian G, Li Y, Deng G, Jiang Y, Liu C, et al. A singleamino-acid substitution in the NS1 protein changes the pathogenicity of $\mathrm{H}_{5} \mathrm{~N}_{1}$ avian influenza viruses in mice. J Virol. 2008;82(3):1146-54. http://dx.doi.org/10.1128/JVI.01698-07. PMid:18032512 PMCid:2224464

26. Kimura M. A simple method for estimating evolutionary rates of base substitutions through comparative studies of nucleotide sequences. J Mol Evol. 1980;16(2):111-20. http:// dx.doi.org/10.1007/BFo1731581. PMid:7463489.

27. González-Reiche AS, Morales-Betoulle ME, Alvarez D, Betoulle JL, Müller ML, Sosa SM, et al. Influenza A viruses from wild birds in Guatemala belong to the North American lineage. PLoS One. 2012;7(3):e32873. http://dx.doi.org/10.1371/journal. pone.0032873. PMid:22427902 PMCid:3302778.

28. Kim HR, Park CK, Lee YJ, Oem JK, Kang HM, Choi JG, et al. Low pathogenic $\mathrm{H} 7$ subtype avian influenza viruses isolated from domestic ducks in South Korea and the close association with isolates of wild birds. J Gen Virol. 2012;93(Pt 6):1278-87. http://dx.doi.org/10.1099/vir.0.041269-0. PMid:22422062. 